\title{
Civil society perspectives on green jobs in sustainable energy: The case of European Malta
}

Author names and affiliations:

Michael Briguglio and Maria Brown

Department of Sociology

University of Malta

Faculty of Arts

Room 305, Old Humanities Building

Msida, MSD 2080

MALTA

Tel. : +356 99894634 / 99404820

michael.briguglio@um.edu.mt

maria.brown@um.edu.mt

Corresponding author: michael.briguglio@um.edu.mt

\begin{abstract}
The objective of this paper is to analyse the perspectives of civil society actors in Malta about the country's sustainable energy policy and its impact on green jobs. Perspectives of 11 civil society actors comprising employers, trade unions and nongovernmental organisations are analysed to provide a broad reflexive analysis of the policy process in question.
\end{abstract}

Findings illuminate a broad consensus within civil society that the policymaking process in the field of sustainable energy should incorporate different voices from civil society - such as employers, trade unions and environmental non-governmental organizations - apart from experts in energy, economics and other areas. Indeed, this study's findings include civil society's reviews on how commercial viability, workers' rights, environmental protection and sustainability interact with and within the sustainable energy sector and related green jobs.

Nonetheless, this study signals that within Maltese civil society, sharing of knowledge and good practice and effort coordination lack. Different interests and sectarianism testify to inconsistently interacting and competing human local networks. This broadens the discourse on effective sustainable energy policy and creation of related green jobs, also making it more complex. Indeed, the direction of such discourse bears potential for sporadic development.

Whilst challenging vertical trajectories, institutionally-centred and secondary-data informed socio-technical transitions in the area of environmental sustainability, the primary data gained from this study highlights need for policy to address the identified challenges through projects, funding and incentives that foster coordination between different types of civil society organisations. 


\section{Highlights}

- A qualitative study that investigates civil society perspectives on green jobs in sustainable energy in the context of Malta, a microstate within the European Union.

- There is a consensus within civil society with respect to the need of increased representation in policymaking.

- Civil society is characterised by lack of coordination and different interests.

- There is a need for policy to address this through projects, funding and other incentives that foster coordination between different types of civil society organisations.

Keywords

Green jobs, sustainable energy policy, civil society, Malta, European Union.

\section{Introduction}

Sustainability underpins the European Union's (EU) energy policy, which is of direct interest in this study. EU directives in this regard promote energy efficiency, renewable energy, mitigation of greenhouse gases and reduction of atmospheric pollution (Streimikiene \& Sivickas, 2008), with goals such as an increase of renewable energy sources to $20 \%$ by 2020, up from $9.8 \%$ in 2010 (Lavecchia \& Stagnaro, 2014, 954).

In turn, EU energy policy is directed by security of supply, competitiveness and environmental protection (Patlitzianas et al., 2008). Sometimes policies are complimentary in their interaction, yet there are also other times when policies have contradictory impacts (Streimikiene \& Sivickas, 2008). For example, when the Government of Malta proposed an offshore wind farm as part of its EU2020 targets, this was in contradiction to the environmental protection policies, such as the Natura 2000 status of the area in question (Briguglio, 2017). In this regard, Carley (2011) notes "there is no discernible or guiding consensus regarding how environmental or social factors should be incorporated into energy calculations and decision-making processes” (211).

In a transparent and accountable decision-making process various stakeholders are involved (Adams et al., 2011). This should not only include energy and environmental experts (Vera \& Langlois, 2007), but also other stakeholders such as civil society representatives. Participatory decision-making should not be seen as a replacement for scientific expertise, but as a 'necessary complement' that broadens the number of dimensions under consideration (Vera \& Langlois, 2007).

The objective of this paper is to analyse the perspectives of civil society actors in Malta with regard to the country's sustainable energy direction and its impact on green jobs. This issue is of importance to the energy policy literature as it concerns the smallest EU member state, which happens to be a small island and which is bound by EU energy targets that include a transition to renewable energy from a near-zero starting point. In this regard, perspectives of civil society actors such as employers, trade unions and non-governmental organisations are deemed as imperative so as to provide a broad reflexive analysis of the policy process in question. 
The article applies existing literature on sustainable development, sustainable energy and green jobs to the issue under analysis, with specific reference to Malta as a EU member state. In this regard, the article adopts a qualitative research method and asks civil society actors to define green jobs, to reflect on the role of different stakeholders in the creation of green jobs, and in evaluating Malta's performance in the creation of such jobs in the sustainable energy sector.

\section{Background and Literature Review}

\subsection{Sustainable Development (SD)}

An overarching feature of SD is targeting consensus by means of negotiation (Beder, 1994). In this regard, the United Nations Economic Commission for Europe (UNECE) (2005) recommends seeking SD through multi-stakeholder partnership between government and local authorities, non-governmental organizations (NGOs) communities and indigenous people. It follows that civil society's role in fostering SD is crucial. Implied challenges are not surprising when considering the multiple dimensions of SD (ranging from environmental protection and sustainable management of natural resources to economic vitality and social justice's (UNECE, 2005); as well as the broad spectrum of stakeholders involved - more so since SD advocates "meeting the needs of the present without compromising the ability of future generations to meet their own needs" (World Commission on Environment and Development (WCED), 1987, 41).

Therefore, sustainable development goes beyond discourses based the belief that science will solve environmental problems (Beder, 1994) without the need for broader social deliberation. The latter is of particular importance so as to help develop a common conceptual framework needed to see a holistic picture (Dale, n.d.).

In the meantime, SD policy discourse may face various forms of resistance (Torgerson, 2003), which, apart from certain business interests, may also include neoliberal ideological orientation, civil service conservatism (Miliband, 1982). Recent research (Pulis et al., 2017) also identified organizational inertia, siloing, NIMBY attitudes, conceptual misunderstandings and mayhem as obstacles, particularly when SD is sought through Education for Sustainable Development (ESD) and within a framework of Lifelong Learning.

Conceptual clarification resurfaces as a recommendation for advocacy groups, policymakers and media in Kouri's and Clarke's (2014) analysis of the framing of green jobs' discourse. The researchers identify discourse fractures that hinder the uptake of green jobs discourse 'as a meaningful concept informing job creation, greening of industry, and sustainable development policy’ (217).

\subsection{Green Jobs}

In the public sphere, sustainable energy policies are often associated with the creation of green jobs. According to the United Nations Environment Programme (UNEP, 2008), green jobs refer to

"work in agricultural, manufacturing, research and development (R\&D), administrative, and service activities that contribute substantially to preserving or restoring environmental quality. Specifically, but not exclusively, this 
includes jobs that help to protect ecosystems and biodiversity; reduce energy, materials, and water consumption through high efficiency strategies; decarbonize the economy; and minimize or altogether avoid generation of all forms of waste and pollution” (3).

The International Labour Organization (n.d.) defines green jobs as

"decent jobs that contribute to preserve or restore the environment, be they in traditional sectors such as manufacturing and construction, or in new, emerging green sectors such as renewable energy and energy efficiency”.

Political parties, environmental NGOs, trade unions, governments, as well as global institutions, such as the United Nations, tend to look at green jobs in sustainable energy favourably. UNEP (2008) estimated the creation of 'more than 8 million jobs in wind and solar alone over the next two decades' (300).

As far as this study is concerned, employment in sustainable energy such as renewable energy production and energy efficiency in industrial processes can both be considered to be green (Scaffrin, 2014; European Environment Agency, 2009).

Such definitions and evaluations may appear straightforward, yet in the real world of policymaking things may be more complicated (Lavecchia \& Stagnaro, 2014). Kouri and Clarke (2012) ask whether all forms of alternative energy and their supply chains should be included as green jobs. One may extend this question by asking whether jobs in sectors such as tourism and nuclear industry (Yi, 2013) can in any way be defined as being green. Consequently, this study verifies the definition of green jobs according to civil society actors.

Moreover, the actual outcomes of green jobs are debatable: In 2007, the European Commission predicted that if the EU reaches its 20\% renewable energy target by 2020 , this would create 650,000 additional jobs $(+0.3 \%)$. Yet, a year later the same EC found a modest decrease in employment related to its energy and climate policies (Lavecchia \& Stagnaro, 2014). Green jobs are also seen as being more volatile than aggregate employment, even in countries characterised by growth in this type of employment, such as Scotland (Connolly et. al., 2015). Focusing on Italy, Lavecchia and Stagnaro (2014) explain this complexity through the fact that the green energy sector tends to be capital-intensive. Green energy may also require higher financial support than conventional energy to be competitive (Schaffrin, 2014). Thus investment in this sector can create fewer jobs than investment in more labourintensive sectors. A study based in the USA by Furchgott-Roth (2012) also reached similar conclusions. This study investigates the validity of such claims in the context of Malta as an EU member-state.

On the other hand, US-based research by Yi (2013) argues that states and local government that invest in green jobs are rewarded with higher employment rates in this sector than other regions. And in Germany, positive net employment effects were reported, even if the large domestic market contributed to this success (Lehr et. al., 2012). Other positive estimates refer to how growth rates in green jobs may outperform other sectors and how new technologies may stimulate innovation in other sectors (Schaffrin, 2014). 
Some scholars argue that the outcomes of green jobs should be seen through a broader perspective than employment figures. The most obvious example would be their positive impacts in terms of clean air and the environment. For example, Pollack (2013) says that green investments help shift society towards a more sustainable and healthier economic model. On the other hand, Furchgott-Roth (2012) is rather sceptical, saying the main impact of green jobs is psychological, as they serve a public relations' function. These types of arguments are analysed in this study in relation to the impacts of green jobs.

\subsection{The Maltese Context}

Research on green jobs in Malta tends to be focused on their future potential. This is hardly surprising given Malta's total dependency on fossil fuel energy prior to the setting of its EU2020 targets (Briguglio, 2017). A study carried out in 2011 (Briguglio et al., 2011) interviewed representatives of trade unions and ENGOs on the matter. Respondents were knowledgeable about the potential of green policies to create jobs and improve the quality of life. They were aware of constraints such as diseconomies of scale, yet they believed that political will could overcome this. Participants in this study emphasised the need for civil society consultation in this regard.

Another study (Damato, 2011) also referred to constraints such as diseconomies of scale and emphasised the need to promote an innovative entrepreneurial climate and to simplify bureaucratic hurdles. On a similar note, it was observed that in Malta there is a lack of preparation of various economic operators in the field of green procurement (Zammit, 2015). Such findings sustain Rizzo’s (2011) appeal for increased political will to shift towards a green economy in Malta.

On the other hand, Rizzo (2011) emphasised that, despite Malta’s small size,

"it qualifies as a mature exponent of development in the global village. Indeed it has all the trappings and characteristics of large nation states. Like other developed and developing countries it managed to build a thriving manufacturing base consisting of a clutch of foreign-based, export-oriented firms. In line with the trends in Europe this sector has been registering a continuous decline” (9).

In the meantime, Malta's Ministry for Sustainable Development, the Environment and Climate Change (MSDEC, 2015) published a consultation document on Malta's green economy, wherein green growth is emphasised. The document refers to studies in 2007 and 2015 showing that green jobs are picking up in relation to sectors such as manufacturing and public services, wastewater and solid waste management. The document also refers to a smaller portion of green jobs in newer sectors such as those related to energy.

A survey carried out in 2016 by the National Statistics Office (NSO) on behalf of MSDEC (2016) used a gross sample of 3,481 workers, of which $81.5 \%$ were employed on a full-time basis and $18.5 \%$ were employed on a part-time basis across 13 different industries. These workers represented $4 \%$ of the total employment within the sectors in question. The study confirmed that water supply, sewerage, waste management and remediation activities had the highest prevalence of green jobs. 
Although findings of this survey suggest that green jobs in the sustainable energy sector are lacking, there must be workers in this sector given that renewable energy in Malta currently accounts for $4.7 \%$ of total energy (Times of Malta, 2016). In this regard, it is important to note that apart from 10\% renewable energy, Malta's EU 2020 energy targets also comprise $10 \%$ bio-fuels and an increase of $5 \%$ of greenhouse gas emissions over 2005 levels by 2020 (MSDEC, 2015, 53).

As a EU member state, the bloc's energy targets and policies bind Malta. This also includes areas such as waste to energy, where stakeholders are conscious of the need to observe EU obligations (Mifsud, 2015). At the same time, however, government tends to resort to top-down decision-making in this sector, despite an increase in stakeholders in policymaking processes (Mifsud, 2015). This style was also conspicuous in the Labour Government's (2013 - to the time of writing) sudden decision to scrap wind energy plans and focus exclusively on solar energy to reach its 10\% renewable energy goal in line with EU targets (Camilleri, 2014; Gerrybaite, 2014). Though a consultation process followed this, the new policy was framed within the remit of solar energy.

Research in Malta shows that such deficits may be effectively addressed by means of stakeholder collaboration through formal, informal and non-formal educational initiatives (Pulis et al., 2017) that target an educated understanding of the values that underpin SD (Briguglio \& Pace, 2004).

Notwithstanding, Malta's policymaking in this regard has been described as being 'fragmentised and erratic' (Gerrybaite, 2014, 69), especially in view of the policy shift in 2014 through which Malta ditched wind energy as part of its renewable energy mix. Since then, Malta shifted Malta's main energy provision from heavy fuel oil to gas and purchase of energy from the European grid through an interconnector with Sicily. Such shifts can be problematic with respect to investors who expect stability and transparency in renewable energy policy (Gerrybaite, 2014). In contrast, the European Commission is encouraging cooperation between competition and sustainable development goals (Gerrybaite, 2014). In turn, this could assist policies aimed towards sustainable energy use through a clear legislative framework. This study verifies civil society's take on such policies whilst identifying respective commonalities and differences within civil society.

\section{Methodology}

The previous sections of this study argued that engagement with civil society is an essential feature of sustainable development, and that the sustainability discourse features in the EU energy policy. In turn, sustainable energy can create green jobs, even though the definition and net impact of the latter are subject to different interpretations and contexts. It was also shown that Malta is aiming to create more green jobs in sectors such as energy in line with its EU2020 targets. At the same time however, questions have been raised on whether Malta has sufficient political will as well as institutional and civil societal preparation for this policy development.

In this regard, this study analyses the perspectives of Maltese civil society organisations regarding green jobs and their potential in the sustainable energy sector. 
In particular, this study investigates to what extent and in what ways are the different relevant civil society organisations in Malta involved in policymaking concerning sustainable energy and related green jobs.

For this purpose, civil society organisations were identified for interviewing in an unrestricted manner (Fricker, 2008) - a sampling technique that is recommended for research with entities that "... exist in such small numbers that probability-based sampling would be unlikely to reach them in sufficient numbers” (p. 17). Civil society entities manifesting interest in sustainable development in Malta at the time of the study comprised 15 environmental NGOs, 5 employers/business organisations, 4 trade unions and 6 think tanks.

Respondents who accepted to be interviewed comprised 3 ENGOs, 3 employers/business organizations, 2 trade unions, and 4 think tanks (Table 1). Moreover, a further employers/business organization, namely, the General Retailers and Traders Union (GRTU), responded to the recruitment letter by referring the researchers to an online press release that GRTU published in 2011 which, according to GRTU, provided sufficient and up-to-date information about GRTU's with the issues being investigated. The researchers accepted by including this secondary source in the data. Therefore, data analysis looked into a total of 11 responses.

In view of its qualitative nature, having a statistically representative sample was not in the remit of this study. Obtaining responses from different types of civil society organisations broadly targeted representativeness of type of organisation. Possible reasons for non-response include that sustainable energy and/or green jobs were not considered to be in direct remit of concern of the specific civil society entity ${ }^{1}$.

\footnotetext{
${ }^{1}$ Indeed, higher non-response by ENGOs validates this since in Malta ENGOs' remit tends to be more focused on traffic concerns, land development, balancing built environment with open spaces, preservation of outside development zones and heritage.
} 
Table 1: Respondents

\begin{tabular}{|c|c|}
\hline Environmental NGOs & $\begin{array}{l}\text { 1. Front for the Protection of Outside } \\
\text { Development Zones (FHO) } \\
\text { 2. Malta Organic Agriculture } \\
\text { Movement (MOAM) } \\
\text { 3. Malta Water Association (MWA) }\end{array}$ \\
\hline $\begin{array}{l}\text { Employers/Business } \\
\text { Organisations }\end{array}$ & $\begin{array}{l}\text { 1. Malta Chamber of Commerce, } \\
\text { Enterprise and Industry (MCC) } \\
\text { 2. Malta Employers Association (MEA) } \\
\text { 3. Malta Developers Association } \\
\text { (MDA) }\end{array}$ \\
\hline Trade Unions & $\begin{array}{l}\text { 1. General Workers Union (GWU) } \\
\text { 2. UHM Voice of the Workers } \\
\text { 3. General Retailers and Traders Union } \\
\text { (GRTU) }\end{array}$ \\
\hline Think Tanks & $\begin{array}{l}\text { 1. Today Public Policy Institute (TPPI) } \\
\text { 2. Ceratonia Foundation (CF) } \\
\text { 3. Academy for the Development of a } \\
\text { Democratic Environment (AŻAD) } \\
\text { 4. Civil Society Network (CSN) }\end{array}$ \\
\hline
\end{tabular}

Fieldwork was carried out using a qualitative survey comprising a structured interview schedule with a mixture of close-ended and open-ended questions. Further to peer review and approval by the University of Malta Research Ethics Committee, the researchers emailed a recruitment letter, a consent form and the structured interview template to the identified civil society organizations. The first responses were considered as pilot and it transpired that the qualitative survey was reaching its aims in a user-friendly manner.

The use of an emailed structured interview limited 'latitude to ask further questions in response to...significant replies’ (Bryman, 2001, 110). On the other hand, this research design facilitated representatives of participating organizations since it did not require them to meet the researchers. This would have been taxing, particularly for NGO representatives who operate on a voluntary basis. The methodology also limited researchers' bias and the Hawthorne Effect. Furthermore, it yielded to standardized responses, thus boosting internal reliability, internal, ecological and measurement validity.

Standardized responses also facilitated thematic and content data analyses to infer and retrieve messages, interpretations and meanings (Schutt, 2015) relevant to the objectives of this study. 


\section{Results and Discussion}

Participating civil society organisations have a broad and holistic understanding of green jobs that goes beyond the greening of the physical environment. This is corroborated by respondents' comprehensive listing of examples of green jobs, such as:

"R\&D on renewable source of energy. People working in the solar energy sector...” (Civil Society Network).

"Technicians, engineers and salespersons in the solar panel importation/installation sector” (Fondazzjoni Ceratonia).

"Photovoltaic panel installers..." (Front Harsien Outside Development Zones (ODZ)).

"One of the most obvious option for green investment in communities is a large-scale building retrofit program to create energy efficiency in buildings, which would rely entirely on known technologies such as ...building-integrated photovoltaic-powered energy, and the installation of efficient appliances” (General Retailers and Trader Union).

The above testify to the predominance of the association of green jobs and sustainable energy with solar energy and photovoltaic panels. Notwithstanding, this was also criticised by a few respondents:

"Malta has pursued solar energy generation. This provides energy only during the daytime. It also goes against the principle of energy diversity being the best way to ensure energy reliability and overcome problems with intermittency and reliability of supply. Leaving wind energy out of our energy mix means that we have only one source of renewable energy and no other source to decrease intermittency” (Today Public Policy Institute).

"...there might be the risk that jobs in the sector will be lost unless the country starts to diversify and exploring other sustainable energy products” (Malta Developers Association).

Civil society perspectives are more fragmented and heterogeneous when evaluating contributions to green jobs and sustainable energy development by authorities and civil society:

(Referring to the contribution of the Government of Malta) "There seem to be only sporadic short term initiatives but there is a lack of conviction about the importance of this sector and hence no long term vision” (Fondazzjoni Ceratonia).

(Referring to the contribution of employers) "Superficial contribution that is mostly linked to green washing and CSR opportunities. There are exceptions of course. www.smartup-project.eu on energy poverty” (Malta Water Association). 
(Referring to the contribution of trade unions)... "The occasional EU funded project, but other than that none at face value (Malta Water Association).

(Referring to the contribution of the Government of Malta) "The National Environment Policy of 2011 identified the green economy as one of its six objectives on the basis of which Malta's environment is to be managed and upgraded. Indeed, this Policy is congruent with the green economy concept that has become an important pillar of major European and international strategies; most notably within the European 2020 strategy adopted by the EU in 2010 to drive sustainable growth, and in the Rio+20 outcome as a means for attaining sustainable development” (General Workers Union).

(Referring to the contribution of the Government of Malta) "Government gives incentives for green projects which impact on the increase of green jobs. Also provides training at various levels of education for those wanting to work in the green energy sector” (Malta Developers Association).

Partisan biases emerge, as in the case of the General Workers Union evaluation of the Government's contribution. The broadness of the spectrum of opinion is also noteworthy - irrespective of whether reference is being made to contributions of the European Union, the state or civil society organisations. For instance, civil society perceptions with respect to the contribution of the European Union range from the EU being the main financial driver, to the role of the EU as a facilitator. As one NGO put it,

"With respect to actual implementation of policies and attaining of specific goals, the EU has little clout to wield" (Front for the Protection of Outside Development Zones).

Another NGO described the EU's contribution as negligible, particularly when it comes to diversification of the sustainable energy sector and proactively addressing long-term effects of harvesting solar energy:

"The EU is doing very little regarding the production of energy from organic wastes, zero action to enhance the production of certified organic fertilizers by organic biogas plants. Zero policy which address steam soil sterilization by solar water heaters...” (Malta Organic Agriculture Movement).

Civil society perceptions on government contribution to green jobs in the sustainable energy sector are negatively assessed, primarily due to national political factors:

"Beyond subsidies for certain sectors like the PV (photovoltaic) industry and Green procurement guidelines, hardly much. On the contrary, the current dismantlement of balances and checks is quickly eroding any environmental considerations or paper obligations. Most efforts remain an afterthought for political discourse or correctness. Drives are mostly focused at moving towards gas and various other top-level/infrastructural switches that unfortunately lack transparency and reek of corruption” (Malta Water Association). 
A recurrent finding of the qualitative survey is the lack of coordination between contributions to the green jobs and sustainable energy sector by different types of civil society organisations. This transpires implicitly and explicitly. Explicit instances that testify to lack of coordination involve unequivocal articulation of the need for a concerted approach, outreach and action:

“... we believe that there is scope for both ENGOs and Developers to come together in order to assuage the worries and conflicts that arise between the two. The two sides have different interests but one thing could bring them together, for example promoting sustainable development, which will be positive on the environment without harming the bottom line of developers” (Malta Chamber of Commerce, Enterprise and Industry).

"A lot of research and initiatives are being carried out by both the government and other various institutions like the University of Malta and other NGOs. Though we feel that not enough emphasis is being made on the dissemination process of such research” (General Workers Union).

This infers that consultative and participative processes are perceived as not exclusively depending on state vision and centralized administration. Civil society efforts in promoting green jobs in sustainable energy testify to inconsistency in coordination between different civil society organisations. Such findings resonate with 'siloing' trends found in a recent study on how state and community-based organisations engage with education for sustainable development (Pulis et al., 2018). Yet they also mirror a deficit in state support for increased coordination within civil society as well as partisan biases in civil society organisations' perceptions. Indeed, fieldwork yielded to only one passing comment that makes generic reference to government's “outreach program in the local community” (General Workers Union) namely, from the Union that shares ideological proximity with the Labour Party, which was in Government at the time of the study.

In this regard, the consultation document Greening our Economy - Achieving a Sustainable Future (MSDEC, 2016) substantiates this analysis: To date, state policy on the greening of the Maltese economy limits the contribution of civil society organizations mainly to the general public, rather than summoning such contributions as part of the core group (MSDEC, 2016). It is also unclear if civil society organizations are given voice through the allocated one-to-one meetings. Albeit, both general public and one-to-one meetings still yield to fragmented, isolated opportunities for civil society contributions. Interestingly, none of the respondents of this study made reference to the consultation document, even though this was advertised in the press and through official channels some months before this study.

On the other hand, implicit instances of lack of coordination between civil society organisations include various respondents' admission of having no knowledge about contributions from other civil society organisations that differ from their own, particularly from trade unions. However, scrutiny of data provided by trade unions yielded to ambivalent outcomes: Whereas UHM Voice of the Workers speaks of limited contribution from the trade union sector to date, data provided by the GWU testify to long-standing commitment: 
"As a trade union, we also believe we can do more to promote green initiatives among our members and possibly consider ways how members could benefit from improved conditions in collective agreements if green initiatives are taken at work place” (Malta Workers Union).

"The GWU has always been conscious of the natural environment issues. As a matter of fact, the GWU (2001 publication) 'Beliefs' dedicates a whole chapter on the environment. We have been advocating and promoting green jobs constantly though out our existence. We believe that the in the near future opportunities of quality jobs in the green economy will increase and thus we need to train enough human resources to fill in these vacancies. Also green jobs in the sustainable energy sector connect to the various sectors of the economy" (General Workers Union).

Thus, whereas think tanks and employers' associations manifest confident knowledge of non-governmental associations' contribution, significant lack or negligible knowledge was manifested by particular trade unions.

Data also confirm that green jobs and sustainable energy are subject to broader economic pressures. Even if sustainable energy industry "will become more important over the next two decades” (Malta Chamber of Commerce, Enterprise and Industry), it was also noted that easier financial gain could be given priority over longer-term sustainability:

"(Employers) are mainly interested in financial gain; most will only offer green jobs if it benefits their company... Too much construction going on. Jobs in construction bring easy money and so less people would be willing to invest in green jobs” (Academy for the Development of a Democratic Environment).

Indeed, the majority of responses see no future for green jobs and sustainable energy in Malta, unless these are underpinned by immediate or medium term corporate financial gain:

"The Private sector will move and adapt in the direction of sustainability if it can be clearly shown that it is profitable to do so in the short to medium term" (Malta Chamber of Commerce, Enterprise and Industry).

"The most difficult part is balancing the environment and economy activity" (General Workers Union).

"Employers respond to market demands - as a relatively young sector it is government which must set out a long term plan and vision" (Ceratonia Foundation).

Economic concerns also feature in civil society perceptions on how Malta's small size affects on green jobs in the sustainable energy sector:

"The small size might make certain initiatives financially unsustainable" (Academy for the Development of a Democratic Environment). 
"Economies of scale always play a part but the green industry is no less affected than other segments” (Malta Chamber of Commerce, Enterprise and Industry).

"Due to its small size, Malta can never compete with other bigger EU states, owing to economies of scale” (Malta Organic Agriculture Movement).

(Malta's small size results in) "(l)imited employment opportunities and brain drain due to frustration, or re-skilling costs to align employees in more 'useable' directions” (Malta Water Association).

The importance given to economic factors for the generation of green jobs is not surprising and tallies with literature quoted earlier in this article. Indeed, EU energy goals give priority to competitiveness apart from security of supply and environmental protection. The challenge to reduce greenhouse gas emissions by $80 \%$ by 2050 can provide much opportunities in this regard (Jones \& Glachant, 2010), calling for decisive policymaking in the field.

Here one should note that countries such as Germany and the Netherlands have been capable of providing green growth due to factors such as long-term policy commitments as well as labour market characteristics (Schaffrin, 2014). To the south of Europe, countries such as Portugal are moving towards green growth through increased investment in sustainable energy (Amaral, 2014). It should also be pointed out that green growth through ecological modernization is not simply within the remit of advanced industrial democracies, as suggested by Frijns et al. (2000, cited in Sutton, 2004). China massive investment in renewable energy is a case in point.

Nevertheless, this study shows that civil society actors in Malta believe that sustainable energy policy has much to gain through their representation. This concurs with the pluralist perspective in that that increased consultation can strengthen the governance process by adding knowledge, accountability, ownership and trust. Despite challenges in the current geopolitical context, more extensive and consensual policymaking through coordinated type capitalism can help strengthen environmental policy (Gough, 2015).

In sum, civil society organisations perceive little or negligible progress achieved during the past five years, which also involved a change in government administration. In fact, results of this study corroborate the need for participative practices showcased by related research carried out in Malta in 2011, referred to earlier in this article (Briguglio et al., 2011; Rizzo, 2011). In this regard it is important to note that the Labour Government elected in 2013 promised a reduction in utility tariffs and a shift from oil towards gas as Malta's main source of energy (Briguglio \& Pace, 2013). Respondents classified the identified change as continuation rather than a major shift of sustainable energy policy; although there is also concern about overreliance on government subsidies. Acknowledgment of progress was coupled to an appeal that far more is required. Data excerpts below testify (respectively):

"Yes (changes have taken place since the change of government in 2013), the power station being the main issue. Reduced electricity tariffs and the government continued working on the good foundations laid pre-2013 as per 
gas plants, sewerage purifier and others" (Malta Organic Agriculture Movement).

"There seems to be a renewed focus on RES (renewable energy sources) especially solar power, nevertheless we still believe that the Industry in itself has become too reliant on Government subsidies" (Malta Chamber of Commerce, Enterprise and Industry).

"Some policies have been designed but are still pending" (Malta Developers Association).

"Yes, we feel that the government is showing more commitment to shift to a greener economy. Still a lot needs to be done and the change should be encouraged and embraced by everyone” (General Workers Union).

Therefore, this study emphasizes the need for more state cooperation with civil society through on-going consultation. This should be matched with evidence-based policymaking, which, for example, can help explain why the Maltese Government is opting for sustainable energy paths.

\section{Conclusions and Policy Implications}

This study has provided a civil society perspective on green jobs and sustainable energy policy development in Malta. Findings inform the understanding of the dispersed and uneven distribution of agency and power, and the importance of (historical, spatial and political) context (Avelino et al. 2016). Indeed, there is evidence of a broad consensus within civil society that the policymaking process in this field should incorporate different voices from civil society - such as employers, trade unions and environmental NGOs - apart from experts in energy, economics and other areas. Substantive policy-making can dwell on the sensitization, broad and holistic understanding of green jobs manifested by civil society. Such voices may raise important social, economic and environmental issues based on civil society entities' experience in their respective fields, such as commercial viability, workers' rights, environmental protection and sustainability.

Whether this is a functional prerequisite of effective policy in sustainable energy is another matter, as can be seen from the Chinese example. Indeed, China is becoming a world leader on renewable energy and has an authoritarian political system. Nevertheless one should note the obvious geo-political and economic differences between the world's largest country and the smallest EU member-state, Moreover, Malta's political system is rooted within a EU framework that gives importance to civil society participation. This kind of policymaking would foster decentralisation of discourse on and democratized engagement with sustainable energy and green jobs.

Nonetheless, this study also signals that within Maltese civil society, sharing of knowledge and good practice and effort coordination are lacking. Policymaking needs to address this lacuna. Moreover, civil society is not a monolith. Different interests and sectarianism, that include partisan biases and alignments, broaden the discourse on what is and how to target effective sustainable energy policy, as well as on the creation of related green jobs. Nonetheless, different interests and sectarianism also 
hinder unidirectional development of such discourse. Moreover, the direction of such discourse cannot be predicted in advance.

Whether lack of coordination between different civil society organisations is restricted to matters related to environmental and sustainable development matters and/or are they correlated to the islands and small states context requires further, possibly country comparative, empirical investigation. It is safe to say, however, that this study highlights need for policy to address this through projects, funding and other incentives that foster coordination between different types of civil society organisations.

Note

Underlying research materials related to this paper comprise textual interview data that can be accessed by contacting the corresponding author. 


\section{References}

Adams M., Wheeler D. and Woolston G., 2011. A participatory approach to sustainable energy strategy development in a carbon-intensive jurisdiction: The case of Nova Scotia. Energy Policy, 39, 2550-2559

Amaral, S. 2014. The Greening of Portugal in a Time of Crisis and Austerity, in: Gale de Oliviera, M.S. et al. (Eds.), The Greening of the Mediterranean. Green Economics Institute, Reading, pp. 139-153.

Avelino, F., Grin, J., Pel, B. and Jhagroe, S. (2016). The politics of sustainability transitions. Journal of Environmental Policy \& Planning, 18(5), 557-567.

Beder, S. 1994. Revoltin' Developments: The Politics of Sustainable Development. Arena Magazine. June-July, 37-39.

Briguglio, L. and Pace, P.J. 2004. Education for Sustainable Development in Malta. Unpublished revised version of a case study prepared for the Expert Meeting on Capacity Development for Sustainable Development in SIDS: Building Partnerships for Sustainable development through Education, Public Awareness and Training University of South Pacific, December 382003.

Briguglio, M. (2017): ENGO Impacts on Climate Change Policy in European Malta. Sociology and Anthropology, 5(4): 269-278

Briguglio M., Brown, M. and Aquilina, D. 2011. A Civil Society Perspective of Sustainable Energy Policy and Green Jobs in Malta as a Small EU State, in: Rizzo, S. (Ed.), Green Jobs from a Small Scale Perspective - Case Studies from Malta. Green European Foundation, Belgium, pp. 10-19.

Briguglio, M., Pace, R. 2013. Malta, in: de Waele, J., Escalona, F. and Vieira, M. (Eds), The Palgrave Handbook of Social Democracy. Palgrave Macmillan, New York, pp. 269-286.

Bryman, A. 2001. Social Research Methods. Oxford University Press, Oxford.

Camilleri, I. 2014. Government shifts renewable energy policy from wind to solar. http://www.timesofmalta.com/articles/view/20141222/local/governmentshifts-renewable-energypolicy-from-wind-to-solar.549303 (accessed 5.01.15).

Carley, S. 2011. Normative Dimensions of Sustainable Energy Policy. Ethics, Policy \& Environment, 14(2), 211-229, doi: 10.1080/21550085.2011.578382

Connolly K., Allen GJ., McIntyre, S.G. 2015. The evolution of green jobs in Scotland: A hybrid approach. Energy Policy, 88, 355-360. 
Dale, A. n.d.. The politics of sustainable development, in: Encyclopedia of Life Support Systems. www.eolss.net/Sample-Chapters/C13/E1-45-04-06.pdf (accessed 28.09.16).

Damato, A. 2011. The Green Industry's Potential to Drive Local Innovation in the Manufacturing Sector, in: Rizzo, S. (Ed.), Green Jobs from a Small Scale Perspective - Case Studies from Malta. Green European Foundation, Belgium, pp. 44-54.

European Environment Agency, 2009. http://glossary.eea.europa.eu (accessed 22.11.16).

Fricker, M. 2008. Reading Ethics: selected texts with interactive commentary. Wiley Blackwell, West Sussex.

Frijns, J., Phung Thuy Phuong, Mol, APJ., 2000. Ecological Modernisation Theory and Industrialising Economies: The Case of Viet Nam. Envirmental Politics 9(1), 257-292.

Furchgott-Roth D. 2012. The elusive and expensive green job. Energy Economics 34, s34-s52.

Gerrybaite, A. 2014. Implementation of Directive 2009/28/EC by Small Member States: Legal issues. Unpublished dissertation (Master of Laws), University of Malta.

Gough, I. 2015 Welfare states and environmental states: A comparative analysis. Environmental Politics, doi: 10.1080/09644016.2015.1074382

International Labour Organisation (ILO), n.d. http://www.ilo.org/global/topics/greenjobs/lang--en/index.htm (accessed 22.11.16).

Jones, C., Glachant, J., 2010. Toward a zero-carbon energy policy in Europe: Defining a viable solution. The Electricity Journal, 23(3), 15-25.

Kouri, R., Clarke, C., 2014. Framing ‘Green Jobs’ Discourse: Analysis of Popular Usage. Sustainable Development, 22, 217-230. doi: 10.1002/sd.1526

Lavecchia, L., Stagnaro, S., 2014. Are green jobs real jobs? The case of photovoltaic power in Italy. Energy \& Environment, 25(5), 953-970.

Mifsud, R. 2015. External influences on Malta's energy sector: A study of multilevel governance at work on the option of waste-to-energy. Unpublished dissertation (Public Policy), University of Malta.

Miliband, R. 1982. Capitalist Democracy in Britain. Oxford University Press, Oxford. 
Ministry for Sustainable Development, The Environment and Climate Change (MSDEC). 2015. Greening our Economy - Achieving a Sustainable Future. MSDEC, Malta. https://socialdialogue.gov.mt/en/Public_Consultations/MSDEC/Document s/Green\%20Economy/Consultation\%20Document\%20\%20Green\%20Economy.pdf (accessed 30.09.16).

Ministry for Sustainable Development, The Environment and Climate Change (MSDEC). 2016. Green employment survey carried out by National Statistics Office on behalf of MSDEC. MSDEC, Malta.

Patlitizianas K.D., Doukas, H., Kagiannas A.G., Psarras, J. 2008. Sustainable energy policy indicators: Review and recommendations. Renewable Energy, 33, 966-973.

Pollack, E. 2013. Environment and Energy: Revitalizing the Green Jobs Agenda. democracyjournal.org. Summer 2013, 46-49.

Pulis, A., Brown, M. and Georgakopoulos, A. 2018. Education for sustainable development in non-formal set-ups: Diagnosing a culture of inertia. In Leal Filho, W., Mifsud, M. and Pace, P. (Eds.) Handbook of Lifelong Learning and Sustainable Development (World Sustainability Series) (pp. 45-59). Cham (Switzerland): Springer.

Rizzo, S. 2011. The Parameters of a Green Sustainable Economy. Rizzo, S. (Ed), Green Jobs from a Small Scale Perspective - Case Studies from Malta, Green European Foundation, Belgium, pp. 7-9.

Schaffrin, A. 2014. The New Social Risks and Opportunities of Climate Change. Fitzpatrick, T. (Ed), International Handbook on Social Policy and the Environment, Edward Elgar, Cheltenham, pp. 3-61

Schutt, RK. 2015. Investigating the Social World: The Process and Practice of Research. SAGE Publications, California.

Streimikiene D. and Sivickas G. 2008. The EU sustainable energy indicators framework. Environment International, 34, 1227-1240.

Sutton, PW. 2004. Nature, Environment and Society. Palgrave Macmillan, New York.

Times of Malta, 2016. http://www.timesofmalta.com/articles/view/20161103/local/wind-powerditched-in-favour-of-solar-as-government-revisits-renewable.629952 (accessed 22.11.16).

Torgerson, D. 2003. Democracy through policy discourse. Hajer, M.A. and Wagenaar, H. (Eds.), Deliberative policy analysis: Understanding governance in the network society. Cambridge University Press, Cambridge, pp. 113-138. 
United Nations Economic Commission for Europe (UNECE). 2005. Strategy for Education for Sustainable Development. UNECE, Vilnius.

United Nations Environment Programme (UNEP). 2008. Green Jobs: Towards decent work in a sustainable, low-carbon world. UNEP, Nairobi.

Vera I. and Langlois L. 2007. Energy indicators for sustainable development. Energy, 32, 875-882

World Commission on Environment and Development (WCED). 1987. Our Common Future. Chapter 2: Towards Sustainable Development: Report of the World Commission on Environment and Development. http://www.undocuments.net/our-common-future.pdf (accessed 05.09.16).

Yi, H. 2013. Clean energy policies and green jobs: An evaluation of green jobs in US metropolitan areas. Energy Policy 56, 644-652.

Zammit, I. 2015. The Introduction of GPP in the Local Government Procurement System - An Analysis. Unpublished dissertation (Executive Masters in Business Administration), University of Malta. 